\title{
都市構造の再編に向けた立地適正化計画の効果的運用に関する研究 STUDY ON EFFECTIVE OPERATION OF LOCATION OPTIMIZATION PLAN FOR RESTRUCTURING OF URBAN STRUCTURE
}

\author{
星 卓志 ${ }^{* 1}$, 野澤 康*2, 松村故英*3, 池上文仁*3 \\ Takashi HOSHI, Yasushi NOZAWA, Akihide MATSUMURA \\ and Fumito IKEGAMI
}

\begin{abstract}
The purpose of this research is to obtain knowledge for effective use of Location Optimization Plan (LOP). Not many cities are actively trying to form a centralized urban structure.

If the ratio of the area of the Dwelling Attraction Area (DAA) to the area of Urbanization Promotion Area is less than 70\%, it is possible to maintain the population density within the DAA.

Many cities do not have active guidance measures to induce DAA residence. However, in some cities, the DAA is narrowed and the residents are actively guided.

Many cities try to maintain their living environment outside the DAA.
\end{abstract}

\section{Keywords : Location Optimization Plan, Urban structure, Attracting dwelling, Effective operation} 立地適正化計画, 都市構造, 居住誘導, 効果的運用

1. はじめに

\section{1 研究の背景と目的}

2014 年に創設された立地適正化計画 (以下「立適計画」という。) 制度について, 2020 年 3 月末時点で, 全国の 522 都市が具体的取組 を, さらに 326 都市が計画の作成, 公表を行っている注1)。これらの 計画立案実績の蓄積の中で, 各自治体の創意工夫により, それぞれ が抱える都市計画上の課題の鮮明化と独自の対応方策の検討が進め られ, 都市計画行政の新しい展開への取り組みが活況を呈している と見ることができよう。

しかしながら, 制度創設から 6 年程度の経過の中で, 同制度がい わゆるコンパクトシティの実現あるいは都市構造の再編にどの程度 の効果を発揮し得るかについての実証的な検証は困難であり, 引き 続き当面は, 効果を期待するという姿勢の中で同制度の活用に取り 組むことを継続せざるを得ない状況にある。

特に, 市街地内の人口分布の再構築を目指すうえでは居住誘導区 域の人口密度を維持するという目標が実現可能であるか, その方法 は何によるのか, 一方で居住誘導区域外の居住者の生活環境は維持 されるのか, といった点については, 多くの自治体における共通の 強い関心事であると考えられる。

そこで本研究では, 市街化区域と市街化調整区域の区分（以下「線
引き」という。)を行っている同計画作成済み都市の取組等から注 2), 居住誘導区域の人口密度維持が可能となる条件について人口推計の 面から検討するとともに, 誘導施策や居住誘導区域外一の取り組み についての事例把握を通して, 都市構造の再編に向けた同計画の効 果的な活用一の知見を得ることを目的とする。

この目的を達成するため, 本研究を次の構成とする。

第 2 章（一部, 第 4,5 章）では, 対象都市の取組み状況を, 上 述の効果的運用の視点から把握する。具体的には, 作成の契機とプ ロセス，期待する効果，区域外への認識や取組みなどである。第 3 章では, 都市構造再編への核心的課題の一つは, 居住誘導区域の人 口密度を維持することにあるため, 作成済み計画について, 人口推 計を踏まえた同区域の人口密度維持の可能性を検討寸る。以上の結 果から, 都市構造再編に向けた居住誘導区域の設定と誘導策につい て積極的な取組みを行っている事例を抽出し, 具体的内容を把握す る (第 4 章)。また, 都市構造再編を強力に推進する際に, 大幅な人 口減少による住環境の悪化が懸念される居住誘導区域外の住環境に ついてどのような方向性で取組むのかについても，立適計画の効果 的活用の一部を構成する内容であると考えられることから, 同区域 外の住環境の維持・向上への取組み状況を把握する (第 5 章)。以上 を踏まえ, 第 6 章において, 総合的な考察を行う。

\footnotetext{
*1 工学院大学建築学部まちづくり学科 教授・博士 (工学)

*2 工学院大学建築学部まちづくり学科 教授・博士 (工学)

* 3 工学院大学大学院工学研究科建築学専攻 修士課程
}

Prof., Dept. of Urban Design \& Planning, Kogakuin University, Ph.D.

Prof., Dept. of Urban Design \& Planning, Kogakuin University, Dr.Eng.

Grad. Student, Dept. of Architecture, Grad. School of Engineering, Kogakuin University 


\section{2 既往研究の動向と本研究の位置づけ}

\section{2.1 既往研究の概観}

立適計画の運用に関わる既往研究（2020 年 3 月時点において, 日 本建築学会計画系論文集, 同学会技術報告集又は日本都市計画学会 論文集に掲載されたもの) は, 次のとおり区分して捉えることがで きる(各区分の特徴的論文を参考文献として挙げる)。

(1)制度活用の全般的な状沉把握 ${ }^{1), 2)}$ : 各都市へのアンケート調查, 計画書の分類整理等により, 計画の導入目的, 誘導区域の設定方法, 誘導施策等を概括的に整理したもの。(2)上位計画との関係性 ${ }^{3)}$ : 都 市計画マスタープランまたは都市計画区域マスタープランといった 上位計画との関係性を，特に拠点（都市機能誘導区域）に着目して 分析したもの。(3)区域設定の考え方や方法 ${ }^{4), 5,6))}$ : 居住誘導区域, 都市機能誘導区域の設定の考え方, 方法, 基準等を, 都市計画マス タープランとの関係, 市街化区域に対する面積比, 災害の危険のあ る区域との関係などの視点を設定して分析したもの。この区分に該 当する研究が最も多い。(4)誘導施策の整理 ${ }^{7)}$ : 居住誘導区域または 都市機能誘導区域への誘導策を把握, 整理し課題を考察したもの。 (5)居住誘導の実現性の検討 ${ }^{8)}$ : 都市機能誘導区域への都市機能誘導 により人口集積を図るという考え方について，実態分析から検討を 行ったもの。(6)市民等の意見による論点 ${ }^{9)}$ : 計画作成過程における 市民等からの意見から, 主要な論点を把握したもの。(7)計画の検証 方法 ${ }^{10)}$ : 将来の人口分布シミュレーションほか, 計画の効果検証の 方法を提案したもの。(8)都市計画法の関連制度との関係 ${ }^{11)}$ : 計画作 成都市における都市計画関係諸制度の運用について把握したもの。

\section{2 .2 本研究の目的に関連する既往研究と本研究の特徵}

本研究の目的と構成 (1.1) に示寸視点からの既往研究の状況は次 のとおりである。

まず, 制度活用の全体的傾向の把握については, 宮崎ほか(2019.6) 1) と尹ほか $(2019.6)^{2)}$ が整理しているが，いずれも 2017 年 7 月時 点で計画の全部または一部を定めている都市を対象としている。

居住誘導区域を設定することによる都市構造目標の設定に関する 研究としては, 尹ほか (2019.10） ${ }^{5)}$ は, 居住誘導区域と都市機能誘 導区域の設定範囲から集約度の視点で類型化, 分析し, 同計画制度 の活用目的等を考察している。西井ほか $(2019.10)^{6)}$ は, 市街化区 域に対する居住誘導区域の面積比率に対応しての計画の特徴を分析 している。

居住誘導区域への居住の誘導策に関する研究として, 星ほか (2019.6) ${ }^{8)}$ は，地方中規模都市内における利便性の高い区域の人 口動向から, 利便性の高さが人口を集積あるいは維持する効果を発 揮し得ない可能性を示唆している。野澤ほか (2019.11） ${ }^{7)}$ は, 立地 誘導の施策として, 都市機能誘導区域内の整備, 居住誘導区域外の 都市計画事業の廃止 - 縮小, 土地利用規制の変更, 居住誘導への支 援策に着目し，全国的な取り組み実態を詳細に把握している。

以上の研究動向の中において, 本研究の特徽は, 2019 年時点の最 新の取り組み状況を把握し, 既往研究の知見を補完すること, 将来 推計人口と維持するとした場合の人口との対比により計画の実現性 を検討すること, 積極的に都市構造の再編に取り組むための立適計 画の活用について検討寸ること, 居住誘導区域外の居住環境につい ての自治体の認識, 取り組みについて把握すること, といった点に ある。

\section{3 研究の方法}

本研究では, 居住誘導区域を定め公表（2019 年 5 月時点）された 157 の線引き都市の立適計画書の分析, アンケート調査及びヒアリ ング調查を，その方法とする。具体的には，各章において詳述する。

\section{2． 線引き都市における立適計画の取り組み状況}

本章では, 2019 年 5 月時点で居住誘導区域を設定済みの線引き都 市へのアンケート調查により, 特に居住誘導区域内の人口を維持す ることに焦点をあて，各自治体の認識を中心に取組み状況を把握す る注 3)。アンケートは, 157 都市に 2019 年 7 月に送付し, 109 都市 (69.4\%) から回答を得た。以下に概要を整理するが，一部（居住誘 導の方法，居住誘導区域外の認識）については，それぞれ 4 章，5 章に記載する。

\section{1 立適計画作成の契機，期待する効果等}

計画作成の契機は（Table 1)，「国から交付金等の支援が受けられ るから」が 84 都市 (77.1\%) で最も多く,「もともとコンパクトシ ティの形成を目指していた中において, 同制度の活用が実現化策と して適当であると考えたから」(78 都市， $71.6 \%)$ という，いわば当 然の契機を上回っている。また「国からの勧奨があったから」(38 都 市，34.9\%）という，主体的ではない契機も約 3 分の 1 の都市が挙 げている。「その他」としては（自由記載の回答について, 類似の内 容を統合的に整理した。以下，同じ。），「時代の変化に対応したまち づくりの方針を示す必要があるから」(4都市),「都市空間の将来像 実現に向けた手法として適しているから」( 3 都市)等が挙げられた。

Table 1 Opportunity to Create Location Optimization Plan (LOP) (Select up to 3 choices) $\mathrm{N}=109$ 立適計画作成の契機 ( 3 肢まで選択)

\begin{tabular}{|c|c|c|}
\hline Choice & $\begin{array}{c}\text { Fre- } \\
\text { quency }\end{array}$ & $\begin{array}{c}\text { Per- } \\
\text { centage }\end{array}$ \\
\hline $\begin{array}{l}\text { Because there was a request from the residents } \\
\text { 住民からの要望があったから }\end{array}$ & 0 & 0.0 \\
\hline $\begin{array}{l}\text { Because there was a request from Assembly } \\
\text { 議会からの要請があったから } \\
\end{array}$ & 1 & 0.9 \\
\hline $\begin{array}{l}\text { There was a recommendation from the national } \\
\text { government 国からの勧奨があったから }\end{array}$ & 38 & 34.9 \\
\hline $\begin{array}{l}\text { Since we originally aimed to form a compact city, we } \\
\text { thought that the utilization of this system was } \\
\text { appropriate as a realization measure. もともとコン } \\
\text { パクトシティの形成を目指していた中において, 同制 } \\
\text { 度の活用が実現化策として適当であると考えたから }\end{array}$ & 78 & 71.6 \\
\hline $\begin{array}{l}\text { Because we can receive support such as grants from } \\
\text { the national government } \\
\text { 国から交付金等の支援が受けられるから }\end{array}$ & 84 & 77.1 \\
\hline $\begin{array}{l}\text { Because it was necessary to promote the } \\
\text { construction of public facilities such as public } \\
\text { hospitals 公立病院など, 公共施設の建設等を推進 } \\
\text { する必要があったから }\end{array}$ & 15 & 13.8 \\
\hline Others その他 & 16 & 14.7 \\
\hline
\end{tabular}

計画作成にあたって重視した地域課題は（Table 2），「都市機能 (商業, 生活サービス等)の衰退, 持続性一の懸念」が 62 都市 (56.9\%) で最も多く, 次いで「人口減少」「既成市街地や中心市街地の人口密 度の低下」が 57 都市 $(52.3 \%)$, 「公共交通の衰退, 持続性への懸念」 が 44 都市 $(40.4 \%)$ である。

立適計画作成により期待する効果・成果は（Table 3)，「既成市街 地等における人口密度の維持, 確保」(97 都市, $90.7 \%$ ), 「生活利便 性の維持，確保（96 都市， 89.7\%）といった制度本来の目的をほと 
んどの都市が挙げつつ,「国からの交付金等の特定財源の確保」(64 都市，59.8\%）を挙げる都市も多い。「その他」としては，「公共交 通ネットワークの維持・強化」(6 都市), 「中心市街地の活性化や地 下上昇」( 5 都市) 等が挙げられた。

都市基盤施設の維持管理コストの変化は (Table 4), 「大きく変化 することはない」（70 都市， $64.2 \%)$ が大半である一方で，「斬新的 に低減することが可能である」は 15 都市 $(13.8 \%)$ に留まるが，「そ の他」の中には,「ある程度の低減が見込まれる」（5都市）や「コ ストの増加抑制が期待される」（2 都市）とする意見もあった。

Table 2 Focused regional issues (Select up to 3 choices) $\mathrm{N}=109$ 重視した地域課題（3肢まで選択）

\begin{tabular}{|c|c|c|}
\hline Choice & $\begin{array}{c}\text { Fre- } \\
\text { quency }\end{array}$ & $\begin{array}{c}\text { Per- } \\
\text { centage }\end{array}$ \\
\hline Population decline 人口減少 & 57 & 52.3 \\
\hline $\begin{array}{l}\text { Increasing aging rate, decreasing comfort for the } \\
\text { elderly 高齢化率の上昇, 高齢者の暮らしやすさの低下 }\end{array}$ & 41 & 37.6 \\
\hline $\begin{array}{l}\text { Decrease in population density in central city area 既 } \\
\text { 成市街地や中心市街地の人口密度の低下 }\end{array}$ & 57 & 52.3 \\
\hline $\begin{array}{l}\text { Concerns about the decline and sustainability of } \\
\text { urban functions (commerce, life services, etc.)都市機 } \\
\text { 能 (商業, 生活サービス等) の衰退, 持続性への懸念 }\end{array}$ & 62 & 56.9 \\
\hline $\begin{array}{l}\text { Location in an inappropriate position from the } \\
\text { viewpoint of the urban structure of urban functions } \\
\text { (commerce, living services, etc.)都市機能（商業, 生活 } \\
\text { サービス等) の都市構造上不適切な位置での立地 }\end{array}$ & 2 & 1.8 \\
\hline $\begin{array}{l}\text { Deterioration of the financial status of the } \\
\text { administration, the need to reduce infrastructure } \\
\text { maintenance costs 行政の財政状況の悪化, インフラ維 } \\
\text { 持管理コストの低減の必要性 }\end{array}$ & 19 & 17.4 \\
\hline $\begin{array}{l}\text { Concerns over the decline and sustainability of } \\
\text { public transportation 公共交通の衰退, 持続性への懸 } \\
\text { 念 }\end{array}$ & 44 & 40.4 \\
\hline $\begin{array}{l}\text { Necessity of improving urban structure and life } \\
\text { assuming the use of private cars 自家用車の利用を前 } \\
\text { 提とした都市構造, 生活の改善の必要性 }\end{array}$ & 9 & 8.3 \\
\hline $\begin{array}{l}\text { Risk of disaster (earthquake, heavy rain/flood, } \\
\text { tsunami, etc.)災害 (地震, 大雨・浸水, 津波等) のリ } \\
\text { スク }\end{array}$ & 15 & 13.8 \\
\hline Other その他 & 11 & 10.1 \\
\hline
\end{tabular}

Table 3 Expected effects of LOP (Select up to 3 choices) $N=109$ 立適計画に期待する効果（ 3 肢まで選択）

\begin{tabular}{lrr}
\multicolumn{1}{c}{ Choice } & $\begin{array}{c}\text { Fre- }^{-} \\
\text {quency }\end{array}$ & $\begin{array}{c}\text { Per- } \\
\text { centage }\end{array}$ \\
\hline Population growth 人口増加 & 5 & 4.7 \\
\hline Improving aging rate 高齢化率の改善 & 3 & 2.8 \\
\hline $\begin{array}{l}\text { Maintaining and securing population density } \\
\text { existing urban areas } \\
\text { 既成市街地等における期待す效果 ( }\end{array}$ & 97 & 90.7 \\
\hline $\begin{array}{l}\text { Maintaining and securing life convenience } \\
\text { 生活利便性の維持, 確保 }\end{array}$ & 96 & 89.7 \\
\hline $\begin{array}{l}\text { Improvement of administrative finance } \\
\text { 行政財政の改善 }\end{array}$ & 14 & 13.1 \\
\hline $\begin{array}{l}\text { Securing specific financial resources such as grants } \\
\text { from the national government } \\
\text { 国からの交付金等の特定財源の確保 }\end{array}$ & 64 & 59.8 \\
\hline $\begin{array}{l}\text { Promotion of disaster prevention and mitigation 防 } \\
\text { 災・減災の推進 }\end{array}$ & 10 & 9.3 \\
\hline Other その他 & 15 & 14.0 \\
\hline
\end{tabular}

Table 4 Awareness of maintenance costs for urban infrastructure (Select 1 choice) $\mathrm{N}=109$ 都市基盤施設の維持管理コストに係る認識（1 肢選択）

\begin{tabular}{|c|c|c|}
\hline Choice & $\begin{array}{c}\text { Fre- }^{-} \\
\text {quency }\end{array}$ & $\begin{array}{c}\text { Per- } \\
\text { centage }\end{array}$ \\
\hline $\begin{array}{l}\text { It is possible to reduce it innovatively } \\
\text { 斬新的に低減することが可能である }\end{array}$ & 15 & 13.8 \\
\hline $\begin{array}{l}\text { Does not change significantly } \\
\text { 大きく変化することはない }\end{array}$ & 70 & 64.2 \\
\hline $\begin{array}{l}\text { May increase temporarily } \\
\text { 一時的に増大する可能性がある }\end{array}$ & 9 & 8.3 \\
\hline Other その他 & 15 & 13.8 \\
\hline
\end{tabular}

\section{2 計画作成手続きと論点}

計画作成過程に実施した意見集約等のための手続きは (Table 5)， 都市計画審議会への説明とパブリックコメントを 9 割以上の都市が 実施し, 約 8 割が議会への説明を，住民説明会は約 7 割が行ってい る。また，外部委員会等の検討組織を設定しているのは，6割超の 都市である。その他としては, 自治協議会への説明（1都市），ポス ターセッション（1 都市）などがわずかに挙げられたが，住民ワー クショップ等のより積極的な住民参加手法は挙げられていない。

議会と都市計画審議会での主な論点としては（Table 6),「居住誘 導区域の設定範囲」が議会 (33 都市, $32.0 \%)$, 都市計画審議会 $(54$ 都市， $49.5 \%$ ）とも多く, 次に「居住誘導区域外の居住環境，持続 可能性等」が議会 : 30 都市, $29.1 \%$, 都市計画審議会 : 44 都市, $40.4 \%$ と, これら 2 項目は共通して関心が高い。一方, 議会では「特 に大きな議論にはなっていない」が 41 都市 $(39.8 \%)$ で回答として は最多である。「その他」としては，議会においては，「上位計画と の整合性」「各方面に分かりやすい計画づくり」(各 2 都市) などが, 都市計画審議会においては, 「災害リスクのある地域における誘導区 域の考え方」( 4 都市),「立適計画における目標値設定の考え方」( 3 都市) などが挙げられている。

Table 5 Procedures carried out (Select all that apply) N=107 実施した手続き（該当する全てを選択）

\begin{tabular}{lcc}
\multicolumn{1}{c}{ Choice } & $\begin{array}{c}\text { Fre- }^{-} \\
\text {quency }\end{array}$ & $\begin{array}{c}\text { Per- } \\
\text { centage }\end{array}$ \\
\hline $\begin{array}{l}\text { Establishment of a review organization such as an } \\
\text { external committee } \\
\text { 外部委員会等の検討組織の設置 }\end{array}$ & 70 & 65.4 \\
\hline $\begin{array}{l}\text { Explanation of the plan to the assembly } \\
\text { 計画案の議会への説明 }\end{array}$ & 88 & 82.2 \\
\hline $\begin{array}{l}\text { Explanation of the plan to the City Planning Council } \\
\text { 計画案の都市計画審議会への説明 }\end{array}$ & 106 & 99.1 \\
\hline $\begin{array}{l}\text { Conducting briefing sessions for citizens } \\
\text { 住民説明会の実施 }\end{array}$ & 77 & 72.0 \\
\hline $\begin{array}{l}\text { Implementation of public comments } \\
\text { パブリックコメントの実施 }\end{array}$ & 102 & 95.3 \\
\hline Other その他 & 17 & 15.9 \\
\hline
\end{tabular}

Table 6 Issues in Assembly and City Planning Council (Select up to 3 choices) $\mathrm{N}=109$ 議会及び都市計画審議会での論点（3肢まで選択）

\begin{tabular}{|c|c|c|c|c|}
\hline \multirow[t]{2}{*}{ Choice } & \multicolumn{2}{|c|}{$\begin{array}{l}\text { Assembly } \\
\text { 議会 }\end{array}$} & \multicolumn{2}{|c|}{$\begin{array}{l}\text { City Planning } \\
\text { Council } \\
\text { 都市計画審議会 }\end{array}$} \\
\hline & $\begin{array}{c}\text { Fre- } \\
\text { quency }\end{array}$ & $\begin{array}{c}\text { Per- } \\
\text { centage }\end{array}$ & $\begin{array}{c}\text { Fre- }^{-} \\
\text {quency }\end{array}$ & $\begin{array}{c}\text { Per- } \\
\text { centage }\end{array}$ \\
\hline $\begin{array}{l}\text { Pros and cons of creating LOP } \\
\text { 立適計画作成の是非 }\end{array}$ & 24 & 22.0 & 21 & 19.3 \\
\hline $\begin{array}{l}\text { Area to set Dwelling Attraction } \\
\text { Area (DAA) } \\
\text { 居住誘導区域の設定範囲 }\end{array}$ & 33 & 30.3 & 54 & 49.5 \\
\hline $\begin{array}{l}\text { Measures to induce residence in } \\
\text { DAA } \\
\text { 居住誘導区域への居住の誘導策 }\end{array}$ & 24 & 22.0 & 40 & 36.7 \\
\hline $\begin{array}{l}\text { Living environment, } \\
\text { sustainability, etc. outside the } \\
\text { DAA 居住誘導区域外の居住環境, } \\
\text { 持続可能性等 }\end{array}$ & 30 & 27.5 & 44 & 40.4 \\
\hline $\begin{array}{l}\text { Number of Urban Function } \\
\text { Attraction Area(UFAA) settings, } \\
\text { position, range, etc.都市機能誘導区 } \\
\text { 域の設定数, 位置, 範囲等 }\end{array}$ & 28 & 25.7 & 44 & 40.4 \\
\hline $\begin{array}{l}\text { Setting urban functions to attracd } \\
\text { 誘導すべき都市機能の設定 }\end{array}$ & 29 & 26.6 & 43 & 39.4 \\
\hline $\begin{array}{l}\text { It has not been a particularly big } \\
\text { discussion } \\
\text { 特に大きな議論にはなっていない }\end{array}$ & 41 & 37.6 & 31 & 28.4 \\
\hline Other その他 & 10 & 9.2 & 16 & 14.7 \\
\hline
\end{tabular}




\section{3 計画作成の効果, 課題}

立適計画作成の過程を経ることで得られた効果 (Table 7) は,「市 街地の変化実態等について詳細な調查・分析ができたこと」（77 都

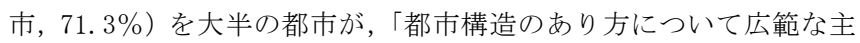
体との議論ができたこと」（53 都市， $49.1 \%$ ）を約半数の都市が挙 げている。また「多様な行政分野間の連携を強化することができた こと」(37 都市， $34.3 \%)$ を約 3 分の 1 の都市が挙げるほか, 「その 他」としては，「自らの自治体を俯瞰することで地域の課題を再確認 することができた」（2 都市）ことなどが挙げられるなど, 計画作成 過程を経たことによる効果として行政内部での意義が強調されてい る。一方,「コンパクトシティの形成について, 多くの住民の理解が 得られたこと」は 12 都市 (11.1\%) のみであり，この点の難しさが 浮き彫りになった。

立適計画作成において課題であった，あるいは対応に苦慮したと 認識していることは（Table 8),「居住誘導区域外となる地域の住民 の中に将来のまちのあり方を不安視する声が多くあったこと」(42 都市, $38.5 \%$ ）と「計画作成の必要性について, 行政内の関係部署 の理解を得ること」(38 都市, $34.9 \%$ ) が比較的多く挙げられてお り，計画の意義の理解を得ることの困難さがうかがえる。「その他」 としては, 「ハザードエリアの扱い」( 5 都市), 「計画の効果を発揮 する具体的な施策の設定」（4都市）などが挙げられた。

Table 7 Positive effects obtained through the planning process (Select up to 2 choices) $\mathrm{N}=108$ 計画作成過程を経ることで得られた成果（2肢まで選択）

\begin{tabular}{|c|c|c|}
\hline Choice & $\begin{array}{c}\text { Fre }^{-} \\
\text {quency }\end{array}$ & $\begin{array}{c}\text { Per- } \\
\text { centage }\end{array}$ \\
\hline $\begin{array}{l}\text { Having discussions with a wide range of actors } \\
\text { about the ideal urban structure } \\
\text { 都市構造のあり方について広範な主体との議論ができ } \\
\text { たここと }\end{array}$ & 53 & 49.1 \\
\hline $\begin{array}{l}\text { Being able to strengthen cooperation between } \\
\text { various administrative fields } \\
\text { 多様な行政分野間の連携を強化することができたこと }\end{array}$ & 37 & 34.3 \\
\hline $\begin{array}{l}\text { Understanding of many inhabitants was obtained } \\
\text { about formation of compact city } \\
\text { コンパクトシティの形成について, 多くの住民の理解 } \\
\text { が得られたこと }\end{array}$ & 12 & 11.1 \\
\hline $\begin{array}{l}\text { Being able to conduct a detailed survey and analysis } \\
\text { of the actual conditions of urban changes 市街地の変 } \\
\text { 化実態等について詳細な調査・分析ができたこと }\end{array}$ & 77 & 71.3 \\
\hline Other その他 & 4 & 3.7 \\
\hline
\end{tabular}

Table 8 Problems in the planning process (Select up to 2 choices) $\mathrm{N}=109$ 計画作成過程での課題（2 肢まで選択）

\begin{tabular}{|c|c|c|}
\hline Choice & $\begin{array}{c}\text { Fre- } \\
\text { quency }\end{array}$ & $\begin{array}{c}\text { Per- } \\
\text { centage }\end{array}$ \\
\hline $\begin{array}{l}\text { Many residents in the areas outside the DAA were } \\
\text { worried about the future of the district. } \\
\text { 居住誘導区域外となる地域の住民の中に将来のまちの } \\
\text { あり方を不安視する声が多くあがったこと }\end{array}$ & 42 & 38.5 \\
\hline $\begin{array}{l}\text { Obtaining the understanding of the relevant } \\
\text { departments within the government regarding the } \\
\text { necessity of planning 計画作成の必要性について, 行 } \\
\text { 政内の関係部署の理解を得ること }\end{array}$ & 38 & 34.9 \\
\hline $\begin{array}{l}\text { To ensure consistency with higher-level plans such } \\
\text { as comprehensive plans and city planning master } \\
\text { plans 総合計画, 都市計画マスタープラン等の上位計画 } \\
\text { との整合性を確保すること }\end{array}$ & 22 & 22.2 \\
\hline $\begin{array}{l}\text { Amended the DAA scope and target population } \\
\text { density settings with advice from government } \\
\text { officials 国の担当者からのアドバイスによって居住誘 } \\
\text { 導区域の範囲や目標とする人ロ密度の設定を修正した } \\
\text { こと }\end{array}$ & 18 & 16.5 \\
\hline Other その他 & 33 & 30.3 \\
\hline
\end{tabular}

\section{3. 居住誘導区域の人口密度維持の可能性}

本章では, 157 都市について, GIS (SIS Map Mode11er 及び QGIS) を使用し，居住誘導区域の人口（密度）の維持の可能性あるいはそ の実現の困難さの度合いを検証する。

居住誘導区域の面積及び人口推計を各都市について同様の方法に より算出するため, 同図を各都市の立適計画書に示される居住誘導 区域をGIS 上でなぞることにより作成する。また，人口データは国 土数值情報ダウンロードサービスの「500mメッシュ別将来推計人口 （H30 国政局推計）（shape 形式版）」を使用し，市街化区域は同サイ トの「都市地域」を使用する。

\section{1 市街化区域に対する居住誘導区域の面積割合}

市街化区域に対する居住誘導区域の面積割合を $10 \%$ 毎に区分した 都市数を Table 9 に示寸注 4 。

市街化区域に対する居住誘導区域の面積割合は $80 \%$ 以上が 71 都市 と，全体の 43.3\%に上り，他方，40\%以下で設定している都市は 9 都 市 $(5.7 \%), 50 \%$ 以下が 23 都市 $(14.6 \%)$ と，居住誘導区域を市街化 区域内で限定的に設定している都市は少ない。Fig. 2 は，上記の面 積割合と市街化区域人口密度との関係を示したものである。高い関 倸性は見られない $\left(\mathrm{R}^{2}=0.2057\right)$ が，市街化区域人口密度が 60 人/ ha 以上の都市の多くでは，居住誘導区域の面積割合が $70 \%$ を超え ている。人口密度が 60 人/ha 以下の大半の都市では, 居住誘導区 域の面積割合が $30 \%$ 以上であるが，都市によって様々である。

Table 9 Area ratio of DAA to Urbanization promotion area $\mathrm{N}=157$ 市街化区域に対する居住誘導区域の面積割合

\begin{tabular}{crrrr}
\hline $\begin{array}{c}\text { Percentage } \\
(\mathrm{p})\end{array}$ & $\begin{array}{c}\text { Number of } \\
\text { Cities }\end{array}$ & $\begin{array}{c}\text { Cumulative } \\
\text { number }\end{array}$ & Percentage & $\begin{array}{c}\text { Cumulative } \\
\text { percentage }\end{array}$ \\
\hline $0<\mathrm{p} \leqq 10$ & 1 & 1 & 0.6 & 0.6 \\
\hline $10<\mathrm{p} \leqq 20$ & 1 & 2 & 0.6 & 1.3 \\
\hline $20<\mathrm{p} \leqq 30$ & 2 & 4 & 1.3 & 2.5 \\
\hline $30<\mathrm{p} \leqq 40$ & 5 & 9 & 3.2 & 5.7 \\
\hline $40<\mathrm{p} \leqq 50$ & 14 & 23 & 8.9 & 14.6 \\
\hline $50<\mathrm{p} \leqq 60$ & 20 & 43 & 12.7 & 27.4 \\
\hline $60<\mathrm{p} \leqq 70$ & 17 & 60 & 10.8 & 38.2 \\
\hline $70<\mathrm{p} \leqq 80$ & 26 & 86 & 16.6 & 54.8 \\
\hline $80<\mathrm{p} \leqq 90$ & 36 & 122 & 22.9 & 77.7 \\
\hline $90<\mathrm{p} \leqq 100$ & 35 & 157 & 22.3 & 100.0 \\
\hline
\end{tabular}

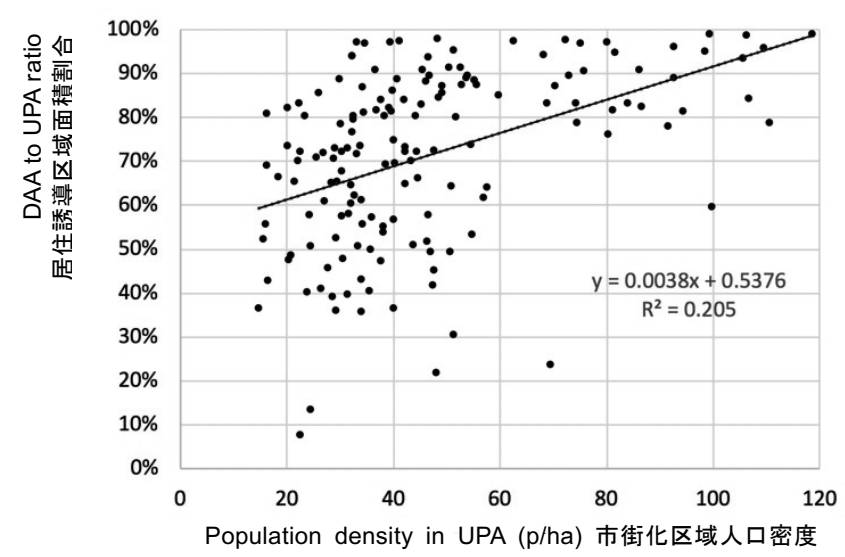

Fig.1 Relationship between population density in Urbanization Promotion Area(UPA) and DAA to UPA ratio 市街化区域人口密度と 居住誘導区域面積割合との関係

3.2 将来推計人ロデータによる人口動向

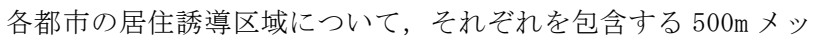


シュを設定し，国立社会保障・人口問題研究所による 2050 年の推 計人口を算出する。それらの 2015 年人口からの増減率別の都市数 をTable 10 に示す。この結果，2050 年に向けて居住誘導区域人口 が $10 \%$ 超増加するとされる都市は，4都市（2.5\%）のみである。 また， $-10 \%$ ～ $10 \%$ の, ほぼ横ばいの都市は 39 都市 $(24.8 \%)$ で あった。残りの約 7 割超の都市は, $10 \%$ 以上減少することとなる。

Table 10 Number of Cities by DAA Population Change Rate (20152050)（N=157） 居住誘導区域の人口増減率別都市数

\begin{tabular}{crr}
\hline $\begin{array}{c}\text { Population change rate } \\
(2015-2050)(\mathrm{r})\end{array}$ & Number of Cities & Percentage \\
\hline $20<\mathrm{r} \leqq 30$ & 1 & 0.6 \\
\hline $10<\mathrm{r} \leqq 20$ & 3 & 1.9 \\
\hline $0<\mathrm{r} \leqq 10$ & 11 & 7.0 \\
\hline$-10<\mathrm{r} \leqq 0$ & 28 & 17.8 \\
\hline$-20<\mathrm{r} \leqq-10$ & 33 & 21.0 \\
\hline$-30<\mathrm{r} \leqq-20$ & 37 & 23.6 \\
\hline$-40<\mathrm{r} \leqq-30$ & 26 & 16.6 \\
\hline$-50<\mathrm{r} \leqq-40$ & 15 & 9.6 \\
\hline$-60<\mathrm{r} \leqq-50$ & 2 & 1.3 \\
\hline$-70<\mathrm{r} \leqq-60$ & 1 & 0.6 \\
\hline
\end{tabular}

\section{3 人口集約による居住誘導区域の人口密度維持の可能性}

「居住誘導区域面積の市街化区域面積に対する割合」に対する 「市街化区域人口の 2050 年までの増減率」を算出（以下「居住誘 導区域内人口密度維持可能性指数」という。）する。この值は, 2050 年までの間で, 仮に, 市街化区域内かつ居住誘導区域外の区 域の人口の全てを居住誘導区域内に集約した場合に, 居住誘導区域 人口密度が維持されると 100 となり，100を下回りその数值が小さ いほど，人口密度の維持の困難性が高まることになる注5)。
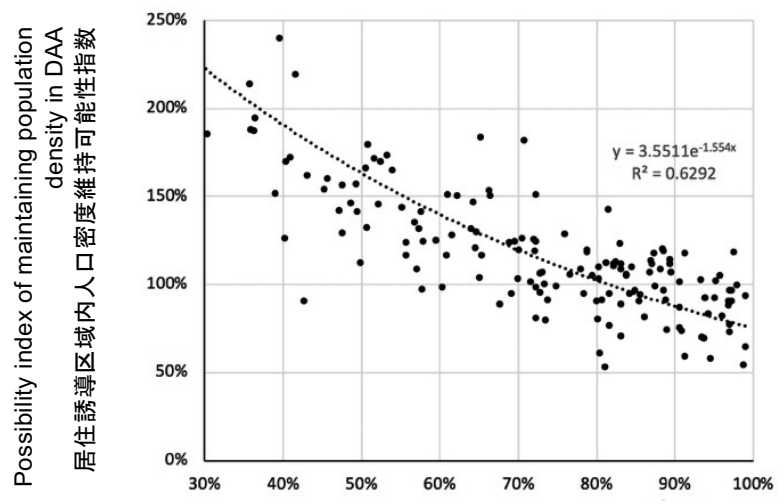

DAA to UPA ratio 居住区誘導区域面積割合

Fig.2 Relationship between DAA to UPA ratio and Possibility index of maintaining population density in DAA 居住誘導区域面積 割合と居住誘導区域内人口密度維持可能性指数との関係
Fig. 2 は，市街化区域に対する居住誘導区域の面積割合と，居住 誘導区域内人口密度維持可能性指数の関係とを示している。両者は 比較的高い説明力 $\left(\mathrm{R}^{2}=0.6292\right)$ を示す。居住誘導区域の面積割合 が $70 \%$ 以下 64 都市中, 同指数が 100 未満の都市は 5 都市のみ

(7. 8\%) である。従って, 同面積割合が 70\%未満の都市の大半で は居住誘導区域の人口密度を維持することが可能であり，面積割合 が小さいほどその可能性は高いと言える。一方，同面積割合が $70 \%$ を超える 93 都市については, 同指数が 100 を超えるのは 49 都市 (52.4\%) となり, 市街化区域の人口動向によっては居住誘導区域 の人口密度維持が困難になることが想定される。

\section{4. 都市構造の再構築に向けた居住誘導区域の設定と誘導策}

本章では，居住誘導区域への誘導策について，国の考え方と前述 のアンケート結果により一般的な傾向を把握したうえで，アンケー 卜の回答, 計画書等から, 積極的な都市構造の再編目標を明示し, そのための独自の施策を展開していると考えられる豊橋市, 刈谷市, 舞鶴市，本庄市の 4 都市を事例として取り上げ，その具体的な取り 組み状況を把握する (各都市の概要を Table 11 に, 各区域の設定状 況を Fig. 3 示す。）各都市については, 2019 年 11 月～2020 年 1 月 にヒアリング及び関連資料の収集を行った。

\section{1 居住誘導策の一般的傾向}

国は，居住誘導区域への居住の誘導のための施策として計画に記 載するべき事項について,「居住誘導区域内の居住環境の向上」と

「公共交通の確保」を挙げ，具体的には，居住環境の向上を図るた め居住者の利便の用に供する施設を整備することと居住誘導区域内 の住宅の立地に対寸る支援措置, 公共交通の確保を図るための交通 結節機能の強化・向上を図ること，さらに基幹的な公共交通網の步 ービスレベルの確保のための施策を例示している注6)。

前述のアンケートの結果, 既に実施している, または検討してい る居住誘導策は,「都市機能誘導区域の生活利便性の向上による居住 地としての魅力の向上」が 87 都市 $(79.8 \%)$ で最も多く, 次いで「居 住誘導区域外の届出対象行為を居住誘導区域内で実施することの勧 奨や勧告」が 33 都市 (30.3\%)，「居住誘導区域内での（集合）住宅 の建設, 同区域内への移転などへの助成金の支出」が 22 都市 $(20.2 \%)$ の順で多くなっている(Table 12)。「その他」としては, 「誘導区域 内での交付金, 補助金などの財政支援または税の減免の実施」( 5 都 市), 「空き家バンク制度の実施等, 空き家対策」( 3 都市) などが挙 げられている。国が重視する公共交通の確保については，2都市の みが挙げている状況である。

\section{Table 11 Overview of DAA, etc. in each city 各都市の居住誘導区域等の概要}

\begin{tabular}{|c|c|c|c|c|}
\hline & Toyohashi 豊橋 & Kariya 刈谷 & Maizuru 舞鶴 & Honjo 本庄 \\
\hline $\begin{array}{c}\text { Total population (National } \\
\text { Census2015) } \\
\text { (change from 2010) }\end{array}$ & $\begin{array}{l}374.8 \text { thousands } \\
(-1.9 \text { thousands })\end{array}$ & $\begin{array}{l}149.8 \text { thousands } \\
(+4.0 \text { thousands })\end{array}$ & $\begin{array}{l}83.9 \text { thousands } \\
(-4.7 \text { thousands })\end{array}$ & $\begin{array}{l}77.9 \text { thousands } \\
(-4.0 \text { thousands })\end{array}$ \\
\hline $\begin{array}{l}\text { Area of UPA(population density) } \\
\text { 市街化区域面積（人口密度） }\end{array}$ & $6,184 \mathrm{ha}(60.6 \mathrm{p} / \mathrm{ha})$ & $2,347 \mathrm{ha}(34.9 \mathrm{p} / \mathrm{ha})$ & $2.134 \mathrm{ha}(39.3 \mathrm{p} / \mathrm{ha})$ & $1,154 \mathrm{ha}(43.0 \mathrm{p} / \mathrm{ha})$ \\
\hline $\begin{array}{c}\text { Fully Decision } y / m \text { of LOP } \\
\text { 立適計画全体作成年月 }\end{array}$ & 2018.9 & 2018.6 & 2018.4 & 2018.3 \\
\hline $\begin{array}{l}\text { Area of DAA } \\
\text { 居住誘導区域面積 }\end{array}$ & 4,278ha & 529ha & $152 \mathrm{ha}$ & $\begin{array}{c}\text { 545ha (445ha in UPA) } \\
\text { (うち市街化区域内:445ha) }\end{array}$ \\
\hline $\begin{array}{c}\text { Ratio to UPA } \\
\text { 市街化区域に対する割合 }\end{array}$ & $69.2 \%$ & $22.5 \%$ & $7.1 \%$ & $38.6 \%$ \\
\hline
\end{tabular}


Table 12 Dwelling attraction way undertaken or under consideration (Select all that apply) $\mathrm{N}=109$

実施済み又は検討中の居住誘導策（該当する全てを選択）

\begin{tabular}{lcc}
\multicolumn{1}{c}{ Choice } & $\begin{array}{c}\text { Fre- }^{-} \\
\text {quency }\end{array}$ & $\begin{array}{c}\text { Per- } \\
\text { centage }\end{array}$ \\
\hline $\begin{array}{l}\text { Encouragement or recommendation to carry out } \\
\text { reportable acts outside the DAA within the DAA }\end{array}$ & 33 & 30.3 \\
居住誘導区域外の届出対象行為を居住誘導区域内で \\
実施することの勧奨や勧告
\end{tabular}

4.2 都市構造の再編を目指した居住誘導区域の設定と居住誘導 の積極的施策展開事例

\section{2.1 豊橋市注 7)}

豊橋市の立適計画は, 都市計画マスタープラン等を具体化したも のとされ，拠点や公共交通幹線軸への機能集積を目的としている。 市街化区域内は都市機能が充実しており, それらの機能の維持に必 要な人口密度も保たれる見込みであることから, これまで通りの居 住を進めていくとしている。この基本的な考え方に基づき,「歩いて

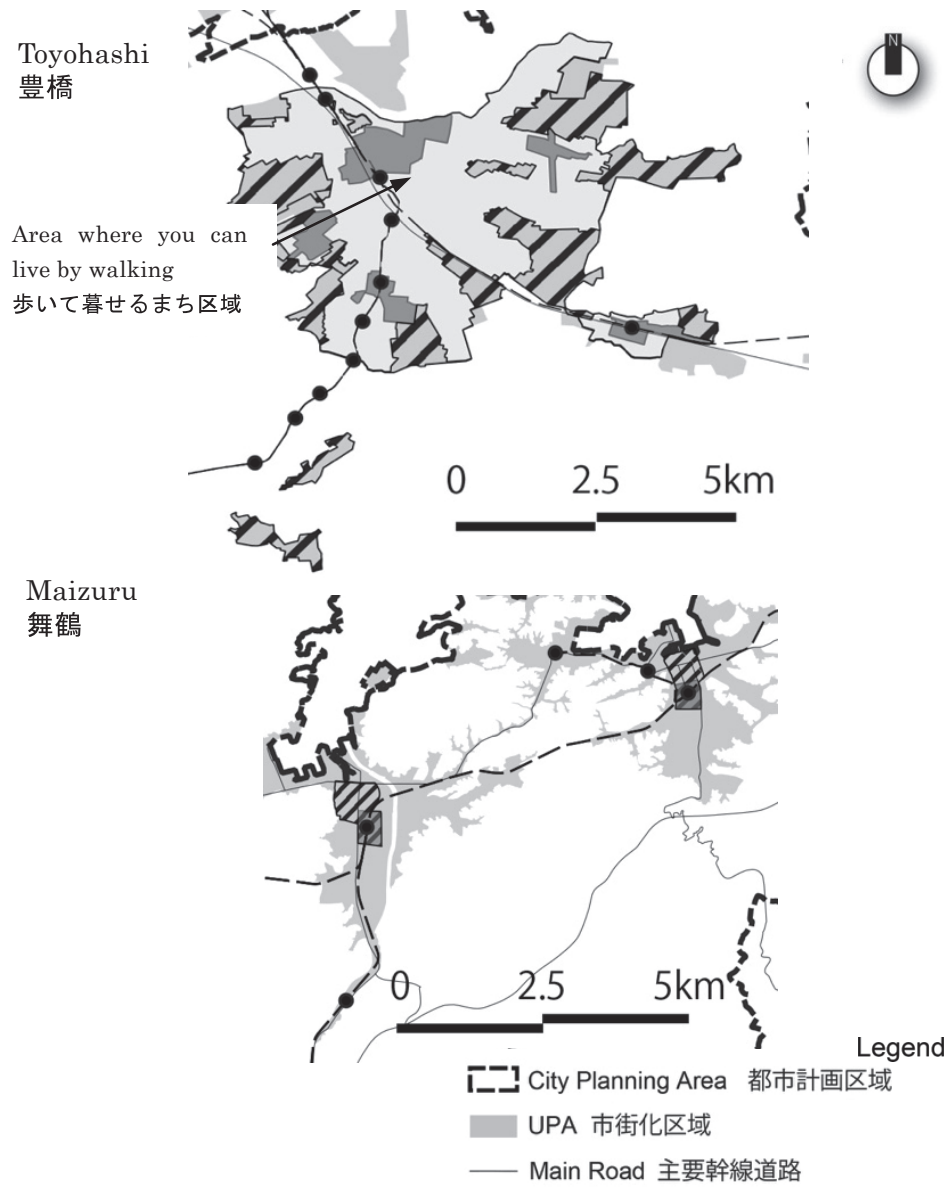

暮らせるまち」「暮らしやすいまち」「持続可能なまち」の実現に向 け，人口減少が顕著な一部市街地での人口密度の上昇，高齢者の生 活支援，世代間バランスの確保等の課題の解決を図るものとしてい る。このため, 市街化区域内でも良好な居住環境を有する市街地を 居住誘導区域（市街化区域の 69.2\%) とし，加えて，特に便利な生活 を送ることができる市街地 $2,792 \mathrm{ha}$ を「歩いて暮らせるまち区域」

（市街化区域の $45.1 \%$ ）と位置づけ，より高密度な人口集積を図る こととしている。目標年（2040 年）の, 居住誘導区域内人口割合を 69. 4\%（2015 年)から 75\%へ, 歩いて暮らせるまち区域内人口を 164.9 千人（2015）から 167.4 千人へ上昇させる目標を設定している。

居住誘導区域への居住の誘導策は, 住宅用地の供給, 空き家等の 利活用を図る誘導策の検討, 雇用の場の確保など，主に計画作成以 前から継続する施策が挙げられている。これに対し，歩いて暮らせ るまち区域一の誘導策は, 定住促進補助金の新設・運用, 子育て応 援奨励金の新設・運用, 空き店舗活用事業について, この区域内で の追加補助などの直接的な支援策のほか，都市機能誘導区域での用 途地域見直し，公共交通に対寸る補助の実施による公共交通の維持 といった, より積極的な誘導策が導入されている。

歩いて暮らせるまち区域一の居住誘導のターゲットとして, 子育 て世代をはじめとする就労世帯をより強力に誘導することを計画し ているため, 特に当該世代に向けた施策が組み込まれている。また, 補助金も同区域に転入してきた子育て世帯が優遇されるものがあり, 積極的に誘導しようとする施策が用意されている。

Kariya 刈谷
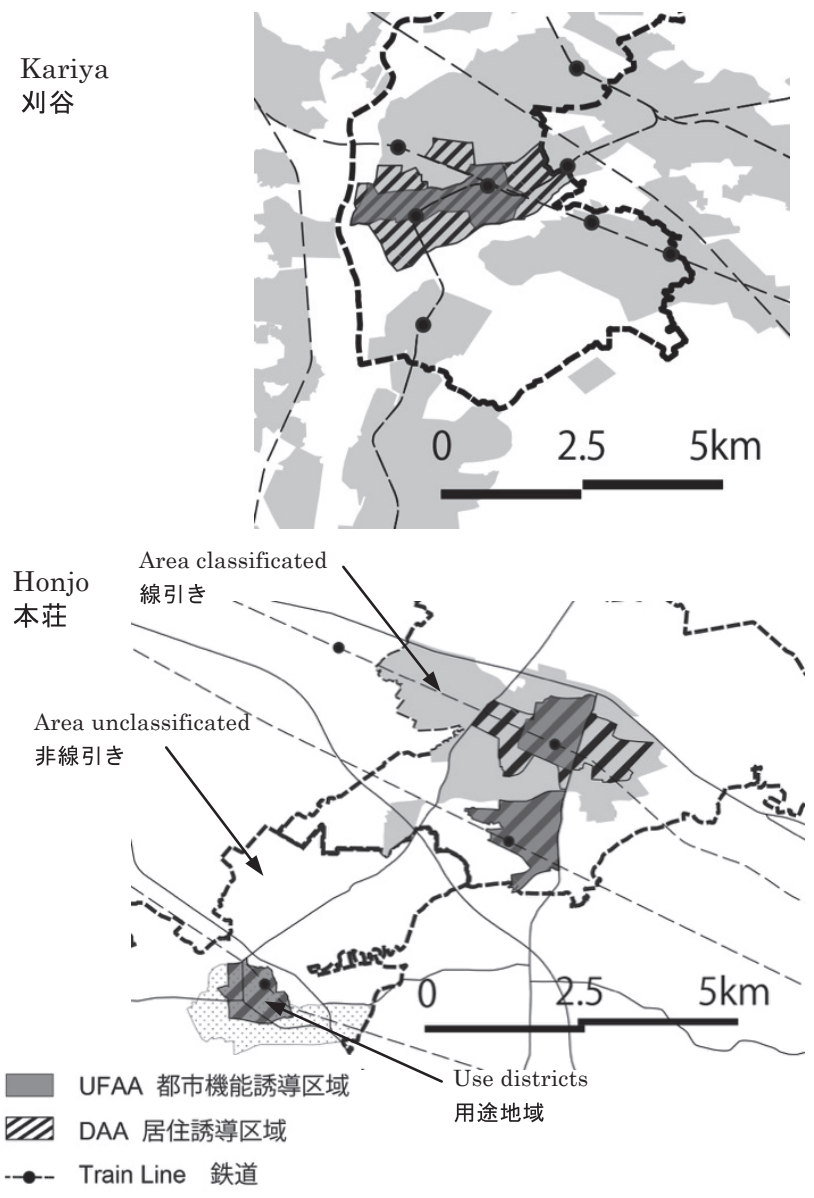

Fig.3 DAA.etc of eachi cities

各都市の居住誘導区域等 


\section{2.2 刈谷市}

刈谷市では, 都市計画マスタープランで掲げた将来都市構造の実 現に向け, 都市・地域拠点に機能誘導を図り, 拠点間を鉄道, バス 等の公共交通機関で結ぶことで, 誰もが歩いて暮らせる「機能集約 型都市構造」を目指している。人口ビジョンにおいて, 2055 年まで 人口増加が予測され， 2060 年に総人口 16 万人を維持することを目 指している。人口が未だ増加傾向にあるため, 居住誘導区域外を含 めた市街化区域全域において居住を推進することとしている。さら に今後の人口増加に伴い, 都市計画マスタープランにおいて, 市街 化区域の拡大検討地区（住居系）が 2 地区位置づけられている。

一方で，市街化区域に対する居住誘導区域の面積割合は $22.5 \%$ と限定的である。ここでは, 人口密度の低下が見られる中心市街地 において, 子育て世代及び高齢者の高い生活利便性確保のために施 設の充実を図り，それら世代を積極的に誘導することとしている。 誘導目標としては, 居住誘導区域内人口密度を 2040 年まで維持 (57. 1 人/ha) するとともに, 中心市街地内の低未利用地割合を $28 \%$ 低減（2013 年 : $8.5 \% \rightarrow 2040$ 年 : $6.1 \%)$ させるとしている。

居住誘導区域一の誘導策は, 住宅供給促進及び良好な住環境形成 促進とで構成されている。前者は, 土地の高度利用や空き家等の有 効活用, 利便性の高い複合施設の立地促進等に加え, 土地利用計画 制度を活用した住工混在地区の用途鈍化による住宅用地の供給等の 促進などである。後者は, 公共交通の利便性向上（鉄道駅等の交通 結節機能の拡充やアクセス性向上, 移動の円滑化に向けた道路や歩 行空間等の確保等), 居住環境の整備(狭险道路の拡幅等の道路整備, 緑地やオープンスペースの確保を目的とした公園整備等）及び子育 て支援施策（子育て関連施設やサービスの円滑な利用促進のための 子育てコンシェルジュ事業の推進, 子育てニーズに対応した切れ目 のない支援・教育環境の充実等) を挙げ, 特に, 高齢者と子育て世 代にとって生活しやすいまちづくりを推進することとしている。

\section{2.3 舞鶴市}

舞鶴市では, 2015 年の「舞鶴市版まち・ひと・しごと創生総合戦 略」（以下「創生戦略」という。）で定めた舞鶴市版コンパクトシテ イの形成に向け, 駅を中心とした「まちなか」の重点的な都市再生 を目的とし, 各種施策を位置づけている。立適計画は, その実現策 の一貫として作成された。都市機能誘導区域, 居住誘導区域ともに, 創生戦略における「まちなか賑わいゾーン」を軸に設定している。 都市機能誘導区域は「まちなか賑わいゾーン」全体の生活の質の向 上に資寸る機能整備により, まちなか創生の拠点となる区域と位置 づけている。居住誘導区域は, 「まちなか賑わいゾーン」のうち, 特 に人口減少が予測され, 重点的な取り組みが求められる区域と位置 づけている。居住誘導区域の面積が 157.7ha（市街化区域の約 $7.1 \%$ ) と, 非常に限定的な区域設定とし, 同区域内人口を 8.1 千人 （2010 年）から 8.6 千人（2040 年）へ増加させる目標としている。 創生戦略に基づき， 2017 年 1 月に用途地域の見直しを行うとと もに, 同年 3 月に区域区分の見直し基準を策定している。用途地域 見直しでは, 住居系の拡大, 商業系の縮小により, 郊外住宅地の第 一種住居地域等の多くを低層住居専用地域, 中高層住居専用地域に 変更し, また, 中心市街地においても商業系用途地域の多くを住居 系に変更するなど, 市街化区域全体にわたり規制強化を行っている。 また，区域区分の見直し基準においては，4つの基準（土地利用
の可能性, 基盤整備の予定, 都市計画上の整合, 将来の人口・産業 への影響）から可能な地域を市街化調整区域一編入検討することと し, 逆線引き候補地（主に丘陵地の谷あいで線状に存在する市街化 区域）を 2017 年 6 月に公表している。

居住誘導策は, 居住環境の安全・安心の確保（狭险街路の再編 成，細分化された空き地の集約等），居住誘導と一体となった商業 区域の再構築（中心的な公園の活用促進に向けた整備, 歴史のみち 整備の促進, 高齢者のまちなか移住促進に資する機能や施設の導入 支援等），空き地・空き家対策の強化（エリア空き家情報バンク制 度，まちなかエリア定住促進空き家再生事業等），働く場の創出に よる移住・定住促進（創生戦略関連施策，高学歴層の雇用・起業支 援等）等を位置づけている。

\section{2 . 4 本庄市}

本庄市には，合併により線引きと非線引きの両都市計画区域があ り, 市街地がそれぞれの中心部 2 箇所に分布している。立適計画は, 線引き市街地の「まちなか再生」, 非線引き市街地の「新しい魅力と 活力あるまちの創造」,さらに「多様なライフスタイルの実現」を基 本方針として作成され, 線引き市街地では, 本庄駅及び本庄早稲田 駅周辺の拠点形成と居住誘導を一体的に促進することとしている。 市街化区域 1,154ha に対して居住誘導区域が 445ha（38.6\%）と限 定的であり，本庄駅周辺においては都市機能誘導区域が約 118ha で あるのに対して居住誘導区域が約 291ha, 本庄早稲田駅周辺では両 者とも約 154ha と一致させており, 上記基本方針の実現への姿勢が 色濃く表れている。誘導目標としては, 居住誘導区域内の人口増減 率（2010 年 $\rightarrow 2040$ 年）を概小 100\%（現状維持）とするとしている。

居住誘導区域一の居住の誘導策は，居住環境整備（民間宅地開発 における道路整備一の補助金, 狭あい道路の改善促進等), 既存ス卜 ックの活用（空き家の建替え補助, 空き家除却後のポケットパーク 化等）ほかを集中的に展開することとしている。

\section{5. 居住誘導区域外の認識と住環境維持への取り組み}

都市構造の再編を目指すにあたり，市街化区域内で居住誘導区域 外の生活環境の方向性は重要な課題であり, 2 章で確認したとおり, 「居住誘導区域の設定範囲」と「居住誘導区域外の居住環境，持続 可能性等」が議会, 都市計画審議会ともに関心が高い。本章では, 市街化区域内の居住誘導区域外についての自治体の認識をアンケー トの結果から把握したうえで, 生活環境維持のための具体的方策に ついて, 事例調査を含め整理する。

\section{1 居住誘導区域外への認識}

前述のアンケートの結果 (Table 13), 居住誘導区域外に対する認 識は，79都市 $(72.5 \%)$ が「住民生活に支障が生じないよう，生活 環境，インフラの維持に努める」，また 26 都市 (23.9\%) が「市街 化区域内としての健全な市街化を促進する」とし, 市街化区域とし ての居住環境水準を重視している。一方，33 都市（30.3\%）が「人 口減少はやむを得ない」とし，居住誘導区域外から同区域内一の居 住誘導の促進，又は人口減少の現実の受け止め姿勢を見せている。 「その他」の中では，「居住に向かない地域である」との回答が最も 多く, 居住誘導区域外としたエリアが, 災害の危険性が高いなど, そもそも居住に適していない地域が市街化区域内に含まれているこ との認識を明らかにしている。また,「地域資源を活かした良好な居 
Table13 Awareness about outside the DAA N=109 居住誘導区域外についての認識

\begin{tabular}{lccc}
\hline \multicolumn{1}{c}{ Choice } & $\begin{array}{c}\text { Fre- }^{-} \\
\text {quency }\end{array}$ & $\begin{array}{c}\text { Per- } \\
\text { centage }\end{array}$ \\
\hline $\begin{array}{l}\text { Strive to maintain living environment and } \\
\text { infrastructure so that residents' lives are not } \\
\text { hindered 住民生活に支障が生じないよう, 生活環境, } \\
\text { インフラの維持に努める }\end{array}$ & 79 & 72.5 \\
\hline $\begin{array}{l}\text { The decline in living environment and the level of } \\
\text { infrastructure is unavoidable } \\
\text { 生活環境, インフラの水準の低下はやむを得ない }\end{array}$ & 5 & 4.6 \\
\hline $\begin{array}{l}\text { Accept deurbanization in the future } \\
\text { 将来的には非市街化を想定している }\end{array}$ & 1 & 0.9 \\
\hline $\begin{array}{l}\text { Promote decent urbanization within UPA } \\
\text { 市街化区域内としての健全な市街化を促進する }\end{array}$ & 26 & 23.9 \\
\hline $\begin{array}{l}\text { Population decline is unavoidable } \\
\text { 人ロ減少はやむを得ない }\end{array}$ & 33 & 30.3 \\
\hline $\begin{array}{l}\text { Aiming to maintain the population } \\
\text { 人ロの維持を目指す }\end{array}$ & 13 & 11.9 \\
\hline Other その他 & 21 & 19.3 \\
\hline
\end{tabular}

住環境の維持・形成を進める」( 4 都市),「独自の地域設定を行い, 適正な環境を維持する」( 3 都市) といった積極的な取り組みもある。

\section{2 居住誘導区域外における生活環境維持の方策}

分析対象の立適計画における居住誘導区域外の居住環境について の言及（届け出制度についての記載を除く）は, 記載無しが 136 都 市 $(86.6 \%)$ と大半である。記載のある 21 都市では, 現状の居住環 境維持の方向性を述べつつ, その方策として, 公共交通ネットワー クの維持・確保, 公共施設等の行政サービスの維持, 地域まちづく りの推進などの施策展開を記載している。ただし, これらは抽象的 であり，具体的な施策の記載は見られない。

アンケート調查結果では (Table 14), 居住誘導区域外の住民の生 活環境の維持方策について, 44 都市 $(40.4 \%)$ が「町内会, 自治体等 の住民コミュニティ活動による共助の体制づくりの促進」を, 41 都 市 (37.6\%)「行政と住民が協働で, 地区単位のまちづくり活動を推 進すること」と, 行政が, 地域単位およびソフト面でのまちづくり に関与し, 住民主体の生活環境維持の推進を目指している。「その他」 としては,「公共交通の利便性を維持・向上させる」（8都市）が最 も多く, 居住誘導区域外の生活環境を維持する上で, 公共交通のあ り方が重要視されている。

Table14 Way to maintain living environment outside the DAA $\mathrm{N}=107$ 居住誘導区域外における生活環境維持の方策

\begin{tabular}{|c|c|c|}
\hline Choice & $\begin{array}{c}\text { Fre }^{-} \\
\text {quency }\end{array}$ & $\begin{array}{c}\text { Per- } \\
\text { centage }\end{array}$ \\
\hline $\begin{array}{l}\text { Promotion of mutual assistance system creation } \\
\text { through community activities such as neighborhood } \\
\text { associations 町内会, 自治会等の住民コミュニティ活 } \\
\text { 動による共助の体制づくりの促進 }\end{array}$ & 44 & 40.4 \\
\hline $\begin{array}{l}\text { Providing administrative services to prevent falling } \\
\text { into so-called marginal settlements } \\
\text { いわゆる限界集落的な状況に陥ることが生じないため } \\
\text { の行政サービスの提供 }\end{array}$ & 24 & 22.0 \\
\hline $\begin{array}{l}\text { Promoting community-based planning activities } \\
\text { through collaboration between the government and } \\
\text { residents 行政と住民が協働で，地区単位のまちづく } \\
\text { り活動を推進すること }\end{array}$ & 41 & 37.6 \\
\hline $\begin{array}{l}\text { We don't think about how to maintain the living } \\
\text { environment } \\
\text { 生活環境の維持方策を特に考えてはいない }\end{array}$ & 14 & 12.8 \\
\hline $\begin{array}{l}\text { We do not intend to maintain the population within } \\
\text { the DAA, and do not assume that the population } \\
\text { outside the area will decrease significantly. } \\
\text { 居住誘導区域内の人ロを維持することとしておらず, } \\
\text { 同区域外の人ロが大きく減少することを想定していな } \\
\text { い }\end{array}$ & 4 & 3.7 \\
\hline Other その他 & 43 & 39.4 \\
\hline
\end{tabular}

このように，計画書への記載はないが，行政として居住誘導区域 外の生活環境維持について配慮，検討している都市は少なくない。

\section{3 生活環境維持の具体的方策の事例}

ここでは，線引き都市が，居住誘導区域外の生活環境を維持する ために, どのような具体的な方策を採っているかについて整理する。

\section{（1）住民との協㗢のまちづくり}

多くの自治体で，行政と住民の協働のまちづくりにより，住民自 らが生活環境を維持していく体制づくりを進めていくとされている。 弘前市では，市民自らが実践するまちづくり，地域づくり活動に 係る経費の一部を支援する「弘前市市民参加型まちづくり $1 \%$ シス テム」のほか， 2015 年には「協働によるまちづくり基本条例」を制 定し, 協働の在り方を具体化したまちづくりの仕組みなどを明確に してきている。また，都市計画マスタープランの策定の際は，「持続 的な地域づくり検討エリア」を含め, 全市において中学校区単位で の地域別構想の策定に取り組み, 住民参加で行うまち育てミーティ ング等により住民意見を取り入れている。このような蓄積を活用し， 居住誘導区域外において地域の課題等を踏まえたまちづくりを目指 していることがヒアリングから明らかとなっている。

\section{（2）日常生活サービスの維持}

居住誘導区域外の人口が将来的に減少することを想定した上で, そこに暮らし続ける住民の生活が务かされることがないよう，公共 施設の更新，インフラの維持，持続可能なコミュニティの形成など を中心として, 日常生活サービスを維持していく方策を採っている。 本庄市や豊橋市では, 維持していくインフラの具体的内容として, 下水道やごみ収集などを想定していることがヒアリングから明らか になっている。札幌市では, 第一種低層住居専用地域の建蔽率を緩 和することで，建て替えの下支えを行い，多様な世代の流入を促進 することで持続可能なコミュニティの形成を目指している。

\section{（3）治安・景観悪化の防止}

居住誘導区域外の人口減少に伴い，空き家や空き地の増加が懸念 される。空き家バンクの活用や，空き家の除却後の公的空間整備な どを行うことで, 空き家, 空き地の増加によって治安, 景観等の周 辺環境の悪化を招かないような取り組みを行う都市が見られた。例 えば，成田市では，立適計画を空家等対策計画と連携させることに よって, 空き家の適正な管理や活用・流通の促進などに努めている。

\section{（4）交通利便性の維持}

居住誘導区域外の生活環境を維持するにあたり, 公共交通の利便 性を維持・向上させることの重要性は多くの都市で認識されている。 具体的には，立適計画に加えて地域公共交通網形成計画を策定する ことにより, 公共交通網を再編し, 都市機能誘導区域や鉄道駅周辺, 支所機能のある拠点地域等とのアクセスを確保したり，市民協働型 の地域公共交通システム，デマンド型バス・タクシーの導入をした りすることなどが方策として挙げられている。例えば，北九州市で は, 交通利便性維持の方策として「お出かけ交通」の運営を実施し ている。運営は, 地域住民, 交通事業者, 行政がそれぞれ役割を持 つて行われており, 市内のバス路線廃止時に伴いルート設定され, 利用者も増加したが, 若年層の利用者が定着せず, 運営の方法やシ ステムのあり方について改善を必要としていることがヒアリングか ら明らかになっている。 


\section{6. まとめと考察}

\section{1 立適計画の活用状況}

立適計画の全国的な取組状況を把握した結果, 既往研究 1),2),7)の 知見を補強し得た事項として, 次の諸点が挙げられる。

(1)導入目的・契機としては, 国からのインセンティブが最も多く, 次に人口密度の維持・向上という点にあること, (2)居住誘導区域の 検討に際しての論点としては, 居住誘導区域外の位置付け・対応に 最も強い関心が持たれていること, (3)誘導区域一の誘導のために具 体的に定めた施策がみられた都市は多くはないこと, (4)居住誘導区 域外について,生活環境の維持に務める方針を持つ都市が多いこと。 一方, 本研究において新たに明らかにしたのは, 次の諸点である。 (1)作成の手続きとして,都市計画審議会への説明とパブリックコメ ントの実施は大半の都市で行っているものの, ワークショップ等の 積極的な住民参加手法は採られていないこと, (2)居住誘導区域外に ついての関心が高いものの, 議会においても特に大きな議論になら なかった都市が多いこと, (3)計画作成過程を経た効果として, 市街 地の変化実態等の詳細調查・分析や都市構造のあり方の議論ができ たことが挙げられ，計画作成が都市の実態や方向性を深く検討する 契機となっている一方, 多くの住民の理解を得るには至っていない こと, (4)課題として, 住民, 行政内部双方で理解を得ることの困難 性が指摘されていること, (5)コンパクトシティ推進の効果として指 摘されることが多い都市基盤施設の維持管理コストの低減について は, そのことの必要性, 期待, 可能性のいずれの面でも, そのよう に認識している都市は少ないこと, (6)区域外の生活環境維持方策と して, 住民コミュニティ活動による共助の体制づくりや, 地区単位 のまちづくり活動の推進を進めるとする都市が比較的多いこと。

以上から, 立適計画の作成は, 制度本来の目的のためである面は あるが, 国からの特定財源の確保等を期待する都市も多く, 国の推 進政策が強く影響している。また, 計画作成プロセスにおける住民 参加手法の導入状況や議会等での議論状況は, 立適計画が地権者等 の権利や義務に直接的に影響を及ぼさない形での区域設定を行うも のであり, 行政主導の計画と認識されていることの表れと考えられ る。このことは, 計画作成過程を経たことの成果として, 市街地の 変化実態等の詳細な調查・分析ができたことや, 都市構造のあり方 について広範な主体との議論ができたことを多くの都市が挙げてい ることや, 住民の理解が必ずしも得られていないことからもわかる。

以上から, 積極的に中心市街地や既成市街地を核と寸る集約型に 都市構造を再編する意思を明確にして立適計画の作成に取り組んで いる都市は, 必ずしも多くはない。

\section{2 都市構造再編に向けた区域設定と誘導策}

市街化区域に対する居住誘導区域の面積割合は，6 割超の都市が $70 \%$ 超えており, 逆に 5 割以下が $15 \%$ 弱と, 限定的に設定してい る都市は少ない。居住誘導区域内人口密度維持可能性指数の試算で は, 人口減少下であっても, 同面積割合が $70 \%$ 未満であれば同区域 内の人口密度を維持することが可能であると考えられるが，多くの 都市では上記面積割合が $70 \%$ 超えており, 同区域の人口密度の低 下を受け入れざるを得ない状況での計画作成となっている。なお， ここでの分析では, 居住誘導区域外が大幅に人口減少することによ り居住環境が悪化することの是非は考慮しておらず，あくまでも数 值上の可能性を検討したのみである。しかし, 市街化区域全体の人
口が減少していく中で, 市街地内の相当程度限定的な範囲であって も, その人口密度を維持することが可能であるとすれば，そのこと にこそ，立適計画制度を活用する意義があると考えられる。

この居住誘導区域への居住誘導策としては, 「都市機能誘導区域の 生活利便性の向上による居住地としての魅力の向上」を大半の都市 が挙げるものの,「居住誘導区域外の届出対象行為を居住誘導区域内 で実施することの勧奨や勧告」が約 3 割，税財政的支援が約 2 割に 留まり，全般的に積極的な誘導策が展開されている状況にはない。

そのような中にあっても，居住誘導区域を市街化区域に比べて特 に狭く設定している舞鶴市 (7.1\%), 刈谷市 $(22.5 \%)$ 及び本庄市 $(38.6 \%)$ は, コンパクトシティの形成に当たって中心拠点となる中心市街地 やまちなかに重点を置き, 都市機能が集積すべき地域への積極的な 居住誘導を目指寸ことで，立適計画に中心市街地活性化策の役割を 持たせようとしている。また，居住誘導区域を二重に設けている豊 橋市では, 居住を維持する区域として居住誘導区域を設けつつ, そ の中で特に利便性の高い区域を「歩いて暮らせるまち区域」とし， 空き家や空き店舗活用等の事業への支援等を手厚く寸ることで，よ り狭い範囲一の積極的な居住誘導を目指している。市街化区域内で の限定的な居住誘導区域の設定とそこへの移住・定住の促進や住環 境向上等の施策を講じることが，拠点となる中心市街地やまちなか の人口を確保し, 集約型の都市構造の形成に有効であるとの認識の もと, 立適計画制度の積極的な活用を図っているものと考えられる。

\section{3 居住誘導区域外の生活環境維持}

計画作成過程での課題として,「居住誘導区域外となる地域の住民 の中に将来のまちのあり方を不安視する声が多くあったこと」が多 く挙げられ，居住誘導区域外について，インフラ等の維持に努め, 住民生活に支障が生じないよう計画作成すべきとする都市が多い。

居住誘導区域外の生活環境維持の方策として, 約 4 割の都市が住 民コミュニティ活動による共助の体制を構築することを挙げており 住民が主体となって自らの生活環境を維持していくことで，行政の 財政的圧迫等を軽減させる狙いがあると推察できる。また, 行政と 住民との協働で地区単位のまちづくり活動を推進することも約 4 割 の都市であげられており, 居住誘導区域外の人口が減少していく中 で，まちづくりの展開を柔軟に実態に合わせていく姿勢がある。

\section{4 今後の課題}

都市構造の変化状況を常に把握, 分析し, 立適計画の効果につい て検証する研究を進める段階に来ていると考える。その際, 都市の 全体構造変化というマクロな視点と, 地域・地区レベルの生活環境 変化のミクロの視点の両面からのアプローチが不可欠である。

その際, 新型コロナウイルス感染拡大防止のための行動変容や意 識変化が, 都市構造のあり方を根底から再設定する必要を迫ること も考えられ，この視点を加味することが不可欠となる。

本研究は, 一般財団法人第一生命財団の 2019 年度研究助成を受 けたものである。

\section{参考文献}

1) Miyazaki,S. Ikaruga,S. Kobayashi,T and Song,J. : Study on the Method of Induction Area and Induction Policy of City which Established Location Optimization Plan, AIJ Journal of Technology and Design, Vol.25, No.60, pp.881-886, 2019.6 (in Japanese) 宮崎慎也，䲥心治，小林剛士，宋俊煥：立適計画策定都市の誘導区域と誘 
導施策に関する研究, 日本建築学会技術報告集, 第 25 巻, 第 60 号, pp. 881886, 2019. 6

2) Yoon,J. Yamaguchi,K. and Kojima,H. : Acture Utilization and Issues of Planning and Operation on Location Normalization Plan System in the Intial Period -the Nationwide Questionnaire Survey-, AIJ Journal of Technology and Design, Vol.25, No.60, pp.905-910, 2019.6 (in Japanese) 尹莊植, 山口邦雄, 小島寛之：立適計画制度の初動期における計画策定と 運用に関する実態と課題 一全国アンケート調査の結果からー, 日本建築学 会技術報告集，第 25 巻，第 60 号，pp. 905-910，2019.6

3) Amakasu,H. Ubaura,M. Kariya,T. and Kochizawa,M. : A Study on Relationship between Planning Contents of the Urban Facility Location Plan and the Urban Planning Master Plan Focusing on the consistency of 'Urban function induction area' and 'Site location optimization plan', Journal of the City Planning Institute of Japan, Vol.53, No.3, pp.400-407, 2018.10 (in Japanese)

甘粕祐明, 姥浦道生, 刈谷智大, 小地沢将之：立適計画と都市計画マスタ ープランの計画内容の関係性に関する研究 - 都市機能誘導区域図と将来都 市構造図の整合性に着目して一, 都市計画学会都市計画論文集, 第 53 巻, 第 3 号, pp. 400-407, 2018. 10

4) Ishihara,S. Nojima,S. and Shikauchi,A. : a Study on Designation Policy of District Centers and Urban Structure on Location Nomalization Plan -Analysis of Setting Central Facilities and Catchment Area in 24 Cities-, Journal of Architecture and Planning (Transactions of AIJ), Vol.84, No.758, pp.883-893, 2019.4 (in Japanese)

石原周太郎, 野嶋慎二, 鹿内愛軌：立適計画における地域拠点の位置づけ 方針と都市構造に関する研究 一中心施設と受け持つエリアの設定から見た 24 都市の構造-, 日本建築学会計画系論文集, 第 84 巻, 第 758 号, pp. 883893, 2019, 4

5) Yoon,J. Yamaguchi,K. and Kojima,H. : A Study on Designation of Area on Two-layer Relation between Location Normalization Plan and Urban Planning - Focusing on Inducing Area Types and Original Area - Journal of the City Planning Institute of Japan,, Vol.54, No.3, pp.516-523, 2019.10 (in Japanese)

尹莊植, 山口邦雄, 小島寛之：立適計画と既存都市計画の二層的構造にお ける区域設定のあり方に関する研究 - 誘導区域の類型区分と独自区域の 活用に着目して -, 都市計画学会都市計画論文集, 第 54 巻, 第 3 号, pp. 516-523, 2019. 10

6) Nishii,S. Manada,R. and Murayama,A. : Policies and Backgrounds for Setting Residential Area in Location Normalization Plans -Through Comparison of Cities with Contrasting Area Ratio of Residential Promotion Area to Urbanization Promotion Area-, Journal of the City Planning Institute of Japan, Vol.54, No.3, pp.532-538, 2019.10 (in Japanese)

西井成志, 真鍋陸太郎, 村山顕人：立適計画における居住誘導区域設定の 考え方とその背景-市街化区域に対する居住誘導区域の面積比率が対象的 な自治体の比較を通じて-, 日本都市計画学会都市計画論文集, 第 54 巻, 第 3 号, pp. 532-538，2019. 10

7) Nozawa,C. Aiba,S. Sanuki,R. Nakanishi,M. and Mochizuki,H. : Issues on the Measures to Induce Residence and Urban facilities with Formulating the Location Normalization Plan - Through the Analysis of a Questionnaire to Municipalities in the Initial Period after the Formulation of the plan -, Journal of the City Planning Institute of Japan, Vol.54, No.3, pp.840-847, 2019.10 (in Japanese)

野澤千絵, 饗庭伸, 讃岐亮, 中西正彦, 望月春花 : 立適計画の策定を機に した自治体による立地誘導施策の取り組み実態と課題 一立適計画制度創設 後の初動期の取り組みに関するアンケート調査の分析-, 日本都市計画学 会都市計画論文集，第 54 巻，第 3 号, pp. 840-847, 2019. 10

8) Hoshi,T. Umehara,K. Hachiya,Y. and Maruoka,T. : Study on Realations with Life Convenience and the Population Distribution Change in Local Cities with Declining Population - Case Study of Hakodate,Aomori and Hachinohe -, Journal of Architecture and Planning (Transactions of AIJ), Vol.84, No.760, pp.1393-1400, 2019.6 (in Japanese)

星卓志，梅原慶，八矢恭昂，丸岡努：人口減少下にある地方都市における 生活利便性と人口分布変化の関係に関する研究-函館, 青森, 八戸を事例と して-, 日本建築学会計画系論文集, 第 84 巻, 第 760 号, pp. 1393-1400, 2019.6
9) Inoue,T. Manabe,R. Murayama,A. Okkata,J. : Significance and Issues of the "Location Normalization Plan" Based on the Intension, Contents, and Points of Discussion : From the Analysis of the Public Comments for the Draft Plans, Journal of the City Planning Institute of Japan, No.17, pp.283-288, 2018.8 (in Japanese)

井上拓男，真鍋陸太郎，村山顕人，大方潤一郎：計画意図・内容と論点か らみた立適計画の意義と課題 - 計画案に対するパブリックコメントの分 析から -, 日本都市計画学会都市計画報告, 第 17 号, pp. 283-288, 2018.8

10) Tsuboi,S. Ikaruga,S. Kobayashi,T. and Nishimura,S. : a Study on the Visualization and Evaluation Method of Compact City Based on Expert System, Journal of Architecture and Planning (Transactions of AIJ), Vol.82, No.731, pp105-114, 2017.1 (in Japanese)

坪井志朗, 鵤心治, 小林剛士，西村祥 ：エキスパートシステムによる集約 型都市構造の可視化と評価手法に関する研究, 日本建築学会計画系論文集, 第 82 巻, 第 731 号, pp. 105-114, 2017. 1

11) Saito,Y. Matsukawa,T. Maruoka,A. Nakade,B. and Higuchi,S. : Study on Policy and Operation of Development Permission System in Cities Making Urban Facility Location Plan, Journal of the City Planning Institute of Japan, Vol.53, No.3, pp.1123-1129, 2018.10 (in Japanese) 齋藤勇貴, 松川寿也, 丸岡陽, 中出文平, 樋口秀：立適計画策定都市での 開発許可制度の方針と運用に関寸る研究，日本都市計画学会都市計画論文 集, 第 53 巻, 第 3 号, pp. 1123-1129, 2018. 10

\section{注}

注 1）国土交通省の集計による。

注 2）ここで線引き都市のみを対象とするのは，市街地の外側（線引き都市 の市街化調整区域, 非線引きの用途地域外）の土地利用の規制状況が異な ること, このため居住誘導区域外の都市計画的位置づけが本質的に異なる ことなどから，同一視点で検討す心゙きではないと考えられることによる。

注 3）全国的な取組み状況は，参考文献 1)，2）及び 7) でそれぞれ把握され ている。本研究において改めて取組み状況を把握することは, 作成済み都 市が増加した中において, 都市構造の再編への立適計画制度の積極的活用 の視点から, 既往研究による知見を強化しうる点と新たに得られた知見と を明確にし，取組み状況への理解の深化に貢献することを意図している。 注 4）市街化区域面積に対する居住誘導区域面積の設定割合を算出して分析 を行った研究としては, 西井ほか（2019）があり ${ }^{6)}$ ，本章はこれを踏まえ た分析となっているが，同論文が 2018 年 10 月時点で居住誘導区域を設定 している 83 都市を対象としているのに対して, 本章の分析対象は 2019 年 5 月時点の 157 都市を対象としている。その上で, 各都市の居住誘導区域 内の将来推計人口（国立社会保障・人口問題研究所）を算出し, 仮に誘導 施策が奏功した場合に居住誘導区域人口密度を維持寸ることが可能かどう かを検討しているところは独自のものである。

注 5）ここで「居住誘導区域面積の市街化区域面積に対する割合」と「市街 化区域人口の 2050 年までの増減率」を用いて人口密度維持の可能性を検 討することの理由は, 次のとおりである。前者について, 居住誘導区域内 人口割合が小さければ同区域の人口密度維持の可能性が高まると考えられ が, ここにおいて, 人口割合ではなく面積割合を用いるのは, 居住誘導区 域の設定が，ある区域内で維持すべき人口の条件で検討するものではな く, 市街地の中のどの範囲とするかを地理的条件で検討し定められるもの であることによる。後者について, 現実には人口減少傾向にある都市が多 くその幅は様々である中においても，居住誘導区域人口密度を維持する限 界（居住誘導区域外の人口がゼロになることを仮定した場合で維持が可能 な範囲）の実態を確認できると考えられることによる。

注 6) 国土交通省：都市計画運用指針 (p38)，IV-1-3，3．（3）-(4)居住 誘導区域内に居住を誘導するために市町村が講ずる施策。

注7）豊橋市の居住誘導区域の市街化区域に対する面積割合は69.2\%（約 7 割）であり，居住誘導区域の設定が限定的とは言えない。また，居住誘導 区域を比較的広く設定した中に, 独自のより限定的な区域を積極的に居 住誘導を図る区域として設定している都市も少なからずある。その中で 豊橋市を本研究の事例対象とするのは，同市においては居住誘導区域一 の居住誘導策は既往制度の継続に留まるのに対し, 独自区域である「歩い て暮らせるまち区域」については, 立適計画作成に伴い多様な誘導策を創 設しており，この区域への積極的な居住誘導を図る意図が明確であると 考えられることによる。 


\title{
STUDY ON EFFECTIVE OPERATION OF LOCATION OPTIMIZATION PLAN FOR RESTRUCTURING OF URBAN STRUCTURE
}

\author{
Takashi HOSHI ${ }^{* 1}$, Yasushi NOZAWA ${ }^{* 2}$, Akihide MATSUMURA*3 \\ and Fumito IKEGAMI*3 \\ ${ }^{* 1}$ Prof., Dept. of Urban Design \& Planning, Kogakuin University, Ph.D \\ *2 Prof., Dept. of Urban Design \& Planning, Kogakuin University, Dr.Eng. \\ ${ }^{* 3}$ Grad. Student, Dept. of Architecture, Grad. School of Engineering, Kogakuin University
}

This study examines from the perspective of population estimation the conditions under which the population density of Dwelling Attraction Area (DAA) can be maintained from the efforts of cities that have created a Location Optimization Olan (LOP). The purpose is to obtain the knowledge for effective use of the LOP for the reconstruction of the city structure by grasping the case examples of the guidance measures and the measures to be taken outside the DAA.

The method of this research is based on the analysis of the appropriate planning documents of 157 cities created and published as of May 2019 (including the analysis of DAA area and future population estimation using GIS), questionnaire survey and hearing.

The promotion policy of the country has a strong influence on the opportunity to create LOP. The effect expected from the planning is consistent with the purpose of the planning system. On the other hand, there are many efforts that expect support from the national government.

In the planning process, there are few active public participation methods. In addition, there are many cities in the parliament that did not have a particularly big debate. Therefore, LOP is recognized as a government-led plan.

Not many cities are actively trying to form a centralized urban structure.

The ratio of the area of DAA to the area of Urbanization Promotion Area (UPA) exceeds $70 \%$ in cities that exceed $60 \%$ of the surveyed cities. On the other hand, less than half of the cities have less than $15 \%$. Therefore, few cities have limited DAA settings. Even if the population is declining, if the ratio of the area of the DAA to the area of UPA is less than $70 \%$, it is possible to maintain the population density within the DAA. However, in many cities, it is over $70 \%$, and it is inevitable to accept the declining population density of DAA.

Many cities do not have active guidance measures to induce DAA residence. Under such circumstances, Maizuru City, Kariya City, and Honjo City, which have a particularly narrow DAA, actively promote their residence to the areas where urban functions should be concentrated, and the central city area is revitalized according to the appropriate plan. Toyohashi City has set up a double DAA and is actively guiding residents to a narrower area. Setting a limited DAA and taking proactive measures for it are considered effective in forming an integrated urban structure.

Many cities are planning outside the DAA with the awareness that they will not hinder the lives of the residents. As a measure to maintain the living environment in areas outside the DAA, about $40 \%$ of cities cite building a system of mutual assistance through community activities. In addition, about $40 \%$ of the cities cite promotion of community-based town development activities in collaboration with the government and residents. As the population outside the DAA continues to decline, it is an attitude to promote urban development in line with the actual situation. 